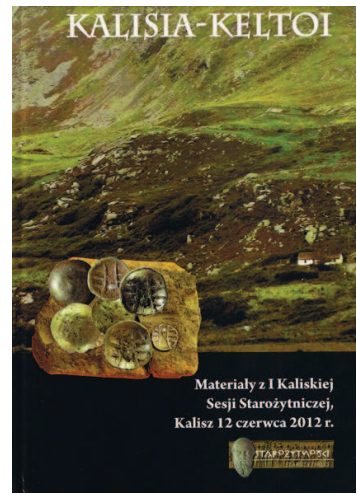

\author{
Mariusz Ciesielski \\ (Bydgoszcz)
}

\title{
O CELTACH
}

DOI 10.14746/SEG.2014.9.19

Kalisia-Keltoi. Materiały z I Kaliskiej Sesji Starożytniczej, Kalisz 12 czerwca 2012 r., pod red. L. Tomczaka i D. Waszaka, Wydawnictwo Napoleon V, Kalisz-Oświęcim 2013, 98 s., z ilustracjami i mapami

Publikacja stanowi zbiór referatów z sesji zorganizowanej w Kaliszu przez Stowarzyszenie „Humanitas”, Muzeum Okręgowe Ziemi Kaliskiej, kaliski oddział Polskiego Towarzystwa Historycznego oraz redakcję czasopisma "Starożytności”. Recenzowana praca jest edycją pierwszego tomu i nową serią wydawniczą, w której według zamierzeń redaktorów tomu, będą ukazywać się materiały tematyczne $\mathrm{z}$ kolejnych sesji, poświęcone wybranym zagadnieniom $\mathrm{z}$ historii starożytnej w „Kaliskich Studiach Starożytniczych”.

Asumptem do jej zwołania była przypadająca w roku 2012 rocznica oblężenia przez Cezara Alezji (52 przed Chr.), oppidum celtyckiego w Galii oraz prowadzone w latach 2007-2011 w okolicach Kalisza badania archeologiczne. Spotkanie zgromadziło miłośników historii, studentów i naukowców z Kalisza, Łodzi, Warszawy i Wrocławia, a ponadto - z racji problematyki poświęconej Celtom - zostało objęte patronatem Honorowego Konsula Irlandii.

Opracowanie jest bardzo ładnie wydane i oprawione w solidną, twardą okładkę. Ilustracje, rysunki oraz dwie mapki będące dopełnieniem tekstu są przejrzyste i ułatwiają zrozumienie tekstu, szczególnie w przypadku opisów zabytków sztuki celtyckiej. Natomiast do mankamentów nieprzystających do szaty graficznej należy w pierwszym rzędzie zaliczyć zauważone dosyć liczne błędy językowe (najbardziej rażące na s. 22, 23, 74, 88), których rozmiary czasami zaskakują i nasuwają podejrzenie o brak rzetelnej korekty tekstu lub przeprowadzenie jej w bardzo pobieżny sposób. Niepotrzebnie obniżają one poziom recenzowanej publikacji i w niektórych miejscach utrudniają zrozumienie treści.

W zamierzeniu organizatorów sesję poświęcono przedstawieniu bogatej kultury celtyckiej jako jednego z filarów europejskiego obszaru kulturowego (s. 5). I w tym wypadku tytuł tomu wydaje się mylący, ponieważ zdaje się sugerować zbiór materiałów przedstawiających życie i kulturę ludności celtyckiej zamieszkującej 
ważny region osadniczy, jakim był Kalisz i jego okolice ${ }^{1}$. Tymczasem zamieszczone artykuły (o czym niżej) dotyczą szeroko pojętej problematyki związanej z ludnością i kulturą celtycką, co samo w sobie nie może być poczytywane jako zarzut, ponieważ koresponduje z przedstawionymi we wstępie założeniami organizatorów sesji, ale wydany zbiór de facto zawiera tylko jeden artykuł ściśle nawiązujący swą tematyką do tytułu tomu², czyli „Kalisia-Keltoi”, a więc terenów leżących wokół Kalisza, jak można się domyślać3. Odrębną kwestię stanowi zasadność łączenia tego wielkopolskiego miasta ze znaną z przekazu Ptolemeusza Kalisią , aczkolwiek $\mathrm{w}$ kontekście badań prowadzonych $\mathrm{w}$ tym rejonie $\mathrm{w}$ szerokim zakresie utrwalone w powszechnej polskiej świadomości skupisko osad znanych pod tą właśnie nazwą stanowi mniej istotny problem. Wszystkie zamieszczone w tomie referaty są zaopatrzone w bibliografię i krótkie streszczenia w języku angielskim, z jednym tylko wyjątkiem w języku hiszpańskim.

Łukasz Krzyszczuk („«Itaque annos non nulli viginti in disciplina permanent», czyli jak zostać druidem”, s. 7-18) przedstawia zarys społeczeństwa celtyckiego

\footnotetext{
${ }^{1}$ Na temat chronologii osadnictwa w tym regionie zob. K. Dąbrowski, Problem starożytnej Kalisii, Dawna Kultura 1, 2, 1954, s. 67; idem, Kalisia Ptolemeuszowa w świetle badań archeologicznych, Warszawa 1961, [maszynopis pracy doktorskiej], Archiwum IHKM PAN w Warszawie, s. 100-101; idem, Kalisz and Its Neighbourhood in the Roman Period, Archeologia Polona 4, 1962, s. 241-242; idem, Uwagi o osadnictwie okolic Kalisza na przełomie er, Rocznik Kaliski 2, 1969, s. 141-142; idem, Kalisz od zarania dziejów do wczesnego średniowiecza, [w:] W. Rusiński (red.), Dzieje Kalisza, Poznań 1977, s. 25-28.

${ }^{2} \mathrm{Na}$ dołączonej do wydania liście referatów wygłoszonych na sesji figurują ponadto opracowania M. Rudnickiego, Osadnictwo celtyckie na ziemiach polskich; T. Baranowskiego, Szlak bursztynowy w okresie lateńskim i rzymskim — problem Calisii przedrzymskiej i rzymskiej; S. Miłka, Importy z celtyckiego kręgu kulturowego na terenie kaliskiego skupiska osadniczego, które nie zostały zamieszczone w recenzowanym tomie.

${ }^{3}$ L. Ziąbka, A. Kędzierski, Uwagi o osadnictwie celtyckich Bojów i ich mennictwie w okolicach Kalisza, [w:] L. Tomczak, D. Waszak (red.), Kalisia-Keltoi. Materiały z I Kaliskiej Sesji starożytniczej, Kalisz 12 czerwca 2012 r., Kalisz-Oświęcim 2013, s. 85-95.

${ }^{4}$ Zob. T. Baranowski, Kalisia. Dlaczego można identyfikować Kalisię Ptolemeusza z Kaliszem nad Prosną?, [w:] S. Suchodolski, M. Zawadzki (red.), Od Kalisii do Kalisza. Skarby doliny Prosny. Katalog wystawy, Zamek Królewski w Warszawie, 30 kwietnia 2010 - 30 maja 2010, b.m.w. [2010], s. 95-99; odmienne stanowisko: Przeworsk-Kultur, [w:] Reallexikon der Germanischen Altertumskunde 23, 2003, s. 549-550; J. Kolendo, Kalisia i Leukaristos - dwa „miasta” w Geografii Ptolemeusza i zagadnienie współrzędnych geograficznych w „Wielkiej Germanii", Światowit 8, B, 2009-2010, s. 77-87; idem, Gdzie powinna być lokalizowana Kalisia Ptolemeusza, [w:] S. Suchodolski, M. Zawadzki (red.), Od Kalisii do Kalisza, s. 91-94; M. Ciesielski, Starożytna Germania i Germanie w polskiej historiografii. Od Adama Naruszewicza po czasy współczesne, Poznań-Gniezno 2011, s. 146-158.
} 
w starożytności, począwszy od pierwszych obserwacji poczynionych przez przedstawicieli świata klasycznego, aż do czasu chrystianizacji Irlandii w V wieku po Chr. (s. 7). Społeczność celtycka miała trójstopniową strukturę, którą łączyła nadrzędna wartość - saor, czyli szeroko pojęta wolność, ograniczona jedynie przez respektowane powszechnie prawo zwyczajowe związane z religią (s. 8). W dalszej części artykułu autor wprowadza czytelnika w tematykę dotyczącą edukacyjnej roli druidów w społeczeństwie celtyckim. Druidzi, czyli ludzie, których „wiedza jest wielka” — jak czytamy w jednej z propozycji etymologii tego słowa (s. 10) - byli kapłanami, jak również pełnili funkcje sądownicze (Caes., Bell. Gall. 6, 13). Uważani byli za ludzi wiedzy - aes dana. Do spektrum ich działalności, poza czynnościami kultowymi, zaliczały się także niektóre dyscypliny nauki, jak filozofia i etyka, a ponadto astronomia, geografia i nauki przyrodnicze (s. 12-13). Cechą charakterystyczną nauczania druidów był brak zapisków i kładzenie nacisku na uczenie pamięciowe (Caes., Bell. Gall. 6, 14), co nadawało ich wiedzy — przekazywanej w sekretnych gajach dębowych - wymiaru mistycznego i tajemnego.

Justyna Maksymowicz („Sakralizacja wojny Celtów”, s. 19-28) rozpoczyna swoje rozważania od przytoczenia informacji przekazanej przez Cezara o wierze ludów celtyckich w coś w rodzaju reinkarnacji (Caes., Bell. Gall. 6, 14) wpajanej przez druidów. Sprawiała ona, że wojowników celtyckich charakteryzowała szalona odwaga i pogarda wobec śmierci ${ }^{5}$. Do jednego z przejawów sakralizacji wojny zaliczało się występowanie w bitwie niektórych celtyckich formacji zupełnie nago (s. 22-23). Miało ono, poza względami praktycznymi, świadczyć właśnie o pogardzie wobec śmierci i wierze $\mathrm{w}$ życie pozagrobowe. Ponadto innym widomym przejawem tego typu wierzeń u ludów celtyckich stał się kult ściętej głowy pozwalający, w przekonaniu jej posiadacza, zawładnąć siłą przynależną pokonanemu wrogowi ${ }^{6}$. Autorka w opisie sakralnych aspektów wojny odwołuje się, podobnie jak jej przedmówca, do znacznej roli druidów, która miała poświadczać głęboki związek tej religii z wojną.

Ilona Skupińska-Løvset („Pergamońskie rzeźby Galatów”, s. 29-38) koncentruje się na rzeźbach Galatów, które są jedynymi zabytkami sztuki w formie rzeźby pełnej ukazującymi Celtów (s. 29). Stanowią swego rodzaju topos rzeźby w dziejach historii sztuki, który był wielokrotnie kopiowany i na stałe wszedł do spuścizny świata starożytnego. Badaczka w dużym skrócie przedstawia genezę i ekspansję kultury lateńskiej w Europie i Azji, aby zatrzymać się na dziejach Galatów osiadłych między

\footnotetext{
${ }^{5}$ J. Rosen-Przeworska, Religia Celtów [w:] J. Keller (red.), Zarys dziejów religii, Warszawa 1988, s. 406.

${ }^{6}$ Eadem, s. 401-402.
} 
rzekami Sangarios a Halys w Azji Mniejszej. Autorka opisuje zachowane marmurowe kopie brązowych rzeźb przedstawiających między innymi „Gala zabijającego żonę i siebie” i „Umierającego Gala” (ilustracje na s. 30 i 32)

W nawiązaniu do toczących się w przeszłości dyskusji pomiędzy historykami sztuki, odnośnie do układu kompozycji rzeźb i rozmieszczenia poszczególnych postaci, badaczka zatrzymuje się na antycznych opisach budowy ciała, wyglądu, stroju i innych atrybutów przypisywanych Galatom. Zauważa, że ówczesna sztuka hellenistyczna, koncentrując się na pokonanych, jakimi w tym wypadku byli Galaci po przegranej z Attalosem I, nawiązywała do dominującego stylu barokowego, który wydawał się odpowiedniejszy do realizacji przedstawień grup rzeźbiarskich.

Dla rzeźbiarza wyzwanie stanowiła możliwość wykazania się swym kunsztem artystycznym w przedstawieniu towarzyszących człowiekowi silnych przeżyć, np. bólu i cierpienia, które należało plastycznie odzwierciedlić w rzeźbie. Do tego celu najbardziej nadawały się przedstawienia barbarzyńców ukazanych w poskręcanych pozach, odmalowujących silne emocje, jako jedną z ujemnych, zdaniem Greków, cech ludów spoza kręgu świata cywilizowanego. Odznaczały się one brakiem umiarkowania i powściągliwości nie tylko w prowadzonych bitwach czy podczas ucztowania, ale także w okazywaniu uczuć, przez zamaszyste, teatralne gesty, polegające między innymi na wyrzucaniu rąk $\mathrm{w}$ akcie rozpaczy czy rezygnacji albo poddania przez opuszczenie głowy na piersi.

Lubomira Tyszler („Elity celto-liguryjskie w rzeźbiarskich przedstawieniach z oppidum w Entremont w południowej Francji”, s. 39-65) na podstawie prowadzonych od XIX w. wykopalisk w dzisiejszym Entremont (nazwa antyczna pozostaje nieznana) w południowej Francji próbuje wyodrębnić grupę elit zamieszkujących tę celto-liguryjską osadę. Bazę materiałową wykorzystaną do analizy naukowej stanowią zachowane źródła ikonograficzne w postaci rytów, reliefów, a także pełnych przedstawień figuralnych.

Przed zajęciem się opisem celto-liguryjskich wyobrażeń figuralnych oraz rekonstrukcją treści ideowych, jakie one niosą, autorka przytacza czytelnikowi w kilkunastu zdaniach informacje o tym, kim były wspomniane ludy zamieszkujące tereny dzisiejszej Prowansji na południu Francji. Poznajemy dzieje pierwszych kontaktów autochtonicznej ludności z Grekami i Rzymianami. Dochodziło wówczas do licznych tarć spowodowanych właśnie powstaniem, w początkach II wieku przed Chr.

\footnotetext{
7 Zob. też J. Rosen-Przeworska, Spadek po Celtach, Wrocław-Warszawa-Kraków-Gdańsk 1979, s. 27, gdzie znajduje się zamieszczone zdjęcie przedstawiające „Gala umierającego na tarczy”, które artystycznym przedstawieniem postaci nawiązuje do przytoczonych przez autorkę przykładów i wpisuje się w topos wizerunku barbarzyńcy.
} 
oppidum celtyckiego leżącego na szlaku handlowym i kierunku greckiej ekspansji. Z czasem, gdy pomiędzy ludnością miejscową a greckimi kolonistami dochodziło do eskalacji nieporozumień i coraz liczniejszych starć militarnych, częstokroć o łupieżczym charakterze, do konfliktu zostali włączeni Rzymianie. Konsekwencją rzymskiej interwencji stało się podbicie terenów zamieszkanych przez miejscową ludność i ostateczne zdobycie Entremont w 123 r. przed Chr. oraz utworzenie rzymskiej prowincji Galia Narbońska (Gallia Narbonensis).

Opisywane stanowisko tworzy kompleks urbanistyczny otoczony murami obronnymi wzmocnionymi wieżami, zajmujący ok. 3,5 ha powierzchni. Składają się na nie budowle publiczne i „dzielnice”, z widocznymi w materiale archeologicznym pozostałościami zabudowy tworzącymi miasto dolne i miasto górne (s. 42-45).

Zabytki z Entremont to, według autorki, ważne miejsce na mapie celtyckiego osadnictwa w Europie. Świadczą o tym pozostałości statui, ich rozmieszczenie przestrzenne i stratygrafia, $w$ tym także ludzkie czaszki znalezione w pomieszczeniu identyfikowanym jako sanktuarium. Opisywane zabytki rzucają nowe światło na życie duchowe ówczesnych mieszkańców, co pozwala zrekonstruować i prześledzić zmiany zachodzące w miejscach kultu w okresie funkcjonowania oppidum.

Autorka próbuje znaleźć odpowiedź na pytanie o czas powstawania statui konnych wojowników, którzy są przedstawiani w pozycji siedzącej, dzierżąc w dłoniach odcięte głowy ludzkie. Ich pojawienie się w Entremont musiało nastąpić, jak wskazują przeprowadzone badania, w momencie wyboru tego miejsca pod osadnictwo, gdzie zostały umieszczone wtórnie. Aczkolwiek nie dowiadujemy się, gdzie mogłyby się one znajdować pierwotnie, zanim zostały sprowadzone do Entremont. Cezurą kończącą w gwałtowny sposób osadnictwo celtycko-liguryjskie w Entremont i wyznaczającą kres funkcjonowania sanktuarium jest moment upadku osady, opuszczonej ostatecznie przez jej mieszkańców ok. 100/90 roku przed Chr.

Zachowane zabytki pozwalają badaczce na analizę poszczególnych warstw społecznych uwiecznionych w kamieniu, prezentując ich wygląd zewnętrzny, strój, ozdoby - gdy chodzi o postaci kobiet, uzbrojenie i tak charakterystyczne dla celtyckiego kręgu kulturowego torkwesy - w przypadku wojowników oraz nie mniej charakterystyczne głowy ludzkie, umieszczane przy łbach końskich lub trzymane w rękach jeźdźców. Symbolika uwiecznionych w kamieniu gestów miała świadczyć o sile i odwadze. Opisywane przedstawienia figuralne znajdują ponadto potwierdzenie $\mathrm{w}$ antycznych przekazach poświęconych deskrypcjom barbarzyńców i ich zwyczajów.

W odniesieniu do stylu artystycznego przedstawień rzeźbiarskich autorka odnotowuje wpływ cywilizacji greckiej także na tę sferę sztuki celtyckiej, która 
sprawiła, że hellenistyczne wzory stały się dla miejscowych artystów inspiracją do ukazywania własnych elit w sposób bardziej monumentalny. Przedstawiane postaci wzorowane na greckich przykładach są ujęte w konwencji wyidealizowanego półboga-herosa, ale zachowują realistyczne rysy twarzy. Ponadto odkryte na powierzchni rzeźb ślady polichromii oddawały kolor skóry, stroju czy ozdób, świadcząc o ich bogactwie w momencie powstania.

Badaczka stawia tezę, że wśród analizowanych rzeźb znajdują się portrety rodziny królewskiej, czego mają dowodzić diademy zdobiące ich głowy i zawiązane na helleńską modłę. Oczywiście artystyczne przedstawienie badanych eksponatów odbiega znacznie poziomem wykonania od greckich wzorów. Brak im tej niedoścignionej doskonałości w odtwarzaniu szczegółów anatomicznych postaci i detalu w przypadku rzeźb głów; zachwiane są także proporcje przedstawianych sylwetek.

W zakończeniu możemy dowiedzieć się o motywach skłaniających lokalne elity do zamawiania tego typu dzieł u miejscowych mistrzów. Jak podaje autorka, także dzięki temu można dostrzec wpływy zwyczajów panujących na dworach monarchów hellenistycznych.

Leszek Tomczak i Damian Waszak („Wybrane epizody z życia świętego Patryka”, s. 67-83) przybliżają wizerunek narodowego patrona Irlandii przez pryzmat jego posługi misyjnej, którą prowadził na Szmaragdowej Wyspie. Autorzy postawili sobie za cel naświetlenie niektórych aspektów działalności świętego, który zwykle jest kojarzony z dniem 17 marca i organizowanymi z wielkim rozmachem paradami ulicznymi. Aczkolwiek w swej istocie życie patrona Irlandii jest mieszaniną faktów i legend, które są bardzo trudne do zweryfikowania, łącznie z ustaleniem roku jego śmierci. Znana jest tylko uroczyście obchodzona data dzienna.

W początkowych partiach artykułu autorzy przybliżają dzieje chrystianizacji Irlandii. Pierwszym poświadczonym źródłowo biskupem był Palladiusz (Palladius), wyznaczony w 431 roku przez papieża Celestyna (Celestinus). Istnieje podejrzenie, że być może Palladiusz nigdy nie dotarł do miejsca pełnienia swojej posługi (s. 67-69).

Urodzony w Brytanii Patryk (Patricius) w młodości został porwany przez piratów i trafił do niewoli na sąsiednią Irlandię, gdzie po kilku latach pobytu nawrócił się na wiarę chrześcijańską. Po ucieczce z niewoli trafił do Galii, gdzie z czasem otrzymał sakrę biskupią i według tradycji postanowił nawrócić swojego dawniejszego pana z lat niewoli. Podczas działalności chrystianizacyjnej w Irlandii musiał zmagać się z obrońcami starych przedchrześcijańskich wierzeń, którzy okazywali przywiązanie do własnych kultów i niechętnie przyjmowali apostoła nowej religii. Jednym z najsłynniejszych sukcesów przyszłego świętego na niwie walki z pogaństwem miał być tzw. pojedynek cudów w Tarze - siedzibie najpotężniejszych 
królów, a raczej królików, wyspy. Zakończył się on, jak podaje legenda, cudownym zwycięstwem biskupa nad iryjskimi druidami i tym samym przypieczętował tryumf chrześcijaństwa (s. 74-78). Po tym doniosłym akcie założono w 444 roku arcybiskupstwo w Armagh. Wydarzenie to, będące źródłem późniejszych sporów o zwierzchnictwo władz kościelnych nad Kościołem irlandzkim, nie bez dyskusji w nauce, przypisuje się Patrykowi (s. 78-80). W zakończeniu autorzy próbują udzielić odpowiedzi na pytanie o rok śmierci świętego i miejsce pogrzebania jego doczesnych szczątków; dane te giną w pomroce dziejów i wciąż budzą naukowe spory.

Zamykający publikację referat autorstwa Leszka Ziąbki i Adama Kędzierskiego („Uwagi o osadnictwie celtyckich Bojów i ich mennictwie w okolicach Kalisza”, s. 85-95) to jedyny, który został poświęcony problematyce ziem polskich w I wieku przed Chr. Autorzy opisują celtyckie osadnictwo w okolicach Kalisza i stawiają dosyć śmiałą i atrakcyjną na pierwszy rzut oka hipotezę o istnieniu w położonym niedaleko Jankowie II w gminie Blizanów mennicy celtyckich Bojów (s. 92).

Jak wiadomo, w okresie przedrzymskim i rzymskim ziemie centralnej i południowej Polski zdominowane były przez osadnictwo kultury przeworskiej. Natomiast dowodem na istnienie w rejonie dzisiejszego Kalisza rozległych kontaktów handlowych miejscowej ludności z innymi ludami i regionami kontynentu są znaleziska, między innymi importów celtyckich. Są to ozdoby, ceramika, przedmioty codziennego użytku i broń. Wśród nich znalazło się także kilka egzemplarzy monet. Uznano je za lokalny wyrób przypisywany osiadłej tutaj grupie ludności z plemienia Bojów z racji stylistycznego podobieństwa do zabytków znanych z terenu Czech. Kolejnym dowodem na poparcie tej hipotezy ma być znaleziona kilkadziesiąt lat temu gliniana płytka, interpretowana jako forma odlewnicza (s. 86). Miała ona służyć do wykonywania monet w specjalnej technice ${ }^{9}$, która sprawiała,

\footnotetext{
${ }^{8}$ Na temat tej kultury i zasięgu jej występowania podaję przykładowo: Przeworska kultura, [w:] Słownik Starożytności Słowiańskich [dalej SSS] 4, 1970, s. 390-393; Przeworsk-Kultur s. 540-567; A. Kokowski, Kultura przeworska — zarys dziejów, [w:] J. Andrzejowski, A. Kokowski, Chr. Leiber, Wandalowie. Strażnicy bursztynowego szlaku, Lublin-Warszawa 2004, s. 25-85; idem, Starożytna Polska, Warszawa 2005, s. 151-176; M. Olędzki, Czas przemian. Barbaricum między Bałtykiem a środkowym Dnieprem w dobie wojen markomańskich, Łódź 2008, s. 60-91. Odrębny problem badawczy stanowią Lugiowie opisani między innymi przez Tacyta (Germ. 43), którzy są utożsamiani właśnie z tą kulturą, przynajmniej na przełomie I-II w. po Chr. Na ten temat zob. J. Kolendo, Komentarz do tekstu „Germanii” Tacyta, [w:] P. Korneliusz Tacyt, Germania, przekład T. Płóciennik, wstęp i kom. J. Kolendo, Poznań 2008, s. 159-169 z przytoczoną literaturą.

${ }^{9}$ A. Kokowski, Starożytna Polska, s. 33-34, 92.
} 
że przybierały one charakterystyczny muszlowy kształt. Na opisywane numizmaty, podobnie jak na przedstawienia rzeźbiarskie, zdecydowany wpływ wywarło mennictwo greckie. Stanowiło ono dla celtyckich mincerzy pierwowzór, z czasem tylko ulegając stylizacji i nabierając lokalnych czysto plemiennych $\operatorname{cech}^{10}$.

Region kaliski może poszczycić się długim, nieprzerwanym okresem zamieszkiwania przez różne grupy ludności. Sprzyjały temu szczególne warunki geograficzne panujące nad rzekami Prosną i Swędrnią oraz korzystna lokalizacja. Jest to obszar o powierzchni około $300 \mathrm{~km}^{2}$ i obejmuje kilkadziesiąt stanowisk archeologicznych $^{11}$. Jednakże uznanie wspomnianych znalezisk monet i surowca służącego do ich wyrobu za ślady po istnieniu w tym rejonie mennicy Bojów (s. 85, 92-93), wydaje się zbyt pochopne. Jest to hipoteza trudna do udowodnienia, przynajmniej na obecnym etapie badań.

Podobieństwo odkrytych numizmatów do monet wytwarzanych przez Bojów wcale nie musi przesądzać o istnieniu na tym terenie ośrodka menniczego, tylko o ewentualnych kontaktach handlowych ${ }^{12}$, co $\mathrm{w}$ tym rejonie, $\mathrm{z}$ racji długotrwałego osadnictwa, nie jest niczym nadzwyczajnym.

Autorzy na poparcie swojej hipotezy przytaczają kilka argumentów. W pierwszej kolejności przywołują Kazimierza Moszyńskiego, który Kalisię powiązał z Celtami. Tymczasem w cytowanym wydaniu, o ile jego treść została dobrze zrozumiana, wspomniany autor, rozpatrując kwestię przynależności etnicznej ludności zamieszkującej okolice Kalisii w okresie rzymskim, jedynie nie wykluczał celtyckiej proweniencji tej nazwy ${ }^{13}$. W dalszej części artykułu autorzy przedstawiają skrótowo dzieje badań archeologicznych prowadzonych w okolicach Kalisza, ale nie podają ani jednego przykładu, poza opisem luźnych znalezisk, który by przekonująco uzasadniał lansowaną przez nich hipotezę o istnieniu celtyckiego ośrodka menniczego lub rzemieślniczo handlowego ${ }^{14}$.

Opisywany teren, jak wiadomo, był ważnym węzłem komunikacyjnym leżącym na szlaku bursztynowym. Trafiało nań mnóstwo przedmiotów z różnych stron

\footnotetext{
${ }^{10}$ Ibidem, s. 92.

${ }^{11}$ M. Ciesielski, Starożytna Germania, s. 153.

${ }^{12} \mathrm{M}$. Olędzki, Ogólne uwagi na temat osadnictwa celtyckiego w Polsce, Prace i Materiały Muzeum Miasta Zgierza, 2, 1997, s. 166-167.

${ }^{13}$ K. Moszyński, Pierwotny zasięg języka prasłowiańskiego, (Prace Językoznawcze 16), Wrocław-Kraków 1957, s. 267; por. J. Kolendo, Kalisia, s. 84, przyp. 46.

${ }^{14}$ K. Dąbrowski, Uwagi, s. 153.
} 
ówczesnego świata. Kilkusetletnie poświadczone archeologicznie osadnictwo ${ }^{15}$ pozostawiło po sobie, co naturalne, ogromną liczbę zabytków i to nie tylko celtyckich. W tym kontekście 12 sztuk odnalezionych numizmatów, także w zestawieniu z innymi monetami z różnych okresów historycznych, zdaje się przeczyć istnieniu w Jankowie mennicy. Gdyby tak było, należałoby tutaj uwzględnić konieczność istnienia zorganizowanej produkcji, co raczej powinno pozostawić ślady bardziej uchwytne w przebadanym materiale archeologicznym ${ }^{16}$.

Niewielka liczba znalezisk z racji swej przypadkowości może tworzyć zaledwie rodzaj wielkości statystycznej i nie odzwierciedla zjawisk jednostkowych lub krótkotrwałych - a za takie chyba nie powinno uznawać się istnienia ośrodka menniczego. Należałoby raczej doszukiwać się w nim charakteru bardziej masowego w ujęciu kwantytatywnym, a ponadto osadzonego w szerszym horyzoncie czasowym i przez to lepiej poświadczonego archeologicznie.

Nie wydaje się także dostatecznym argumentem świadczącym o istnieniu w tym rejonie mennicy twierdzenie, że badane numizmaty nie były skarbem, ponieważ zostały znalezione w kilku miejscach, miały wyciśnięte odmienne rodzaje stempli, a poszczególne egzemplarze różniły się składem chemicznym stopu kruszcu, z którego zostały wykonane (s. 93). Pomimo wcześniejszych uwag, dowodzi to raczej przypadkowości znalezisk i ewentualnym pojawieniu się w tym rejonie monet celtyckich drogą handlu lub wymiany, jak to zazwyczaj działo się w przypadku monet rzymskich ${ }^{17}$.

Analogicznie przedstawia się sytuacja ze znalezioną glinianą płytką służącą do odlewania monet. Niewykluczone, że także mogła być importem i znaleźć się na omawianym terenie zupełnie przypadkowo. A ponadto, jak odnotowali autorzy, $\mathrm{w}$ przeszłości jej przeznaczenie i datowanie były interpretowane zgoła odmiennie i uznawano ją nawet za wytwór kultury łużyckiej o przeznaczeniu kultowym $(\text { s. 86 })^{18}$. Jeśli jednak najnowsza interpretacja jest trafna i pozwala uznać tę płytkę za formę służącą do odlewania monet, to również jest to znalezisko luźne i przez to mało przekonujące $\mathrm{w}$ kontekście uznania istnienia mennicy. Pozostaje także kwestia stempli do monet, o których w badanym rejonie nie ma żadnej wzmianki.

\footnotetext{
${ }^{15}$ Idem, Kalisia, s. $100-101$.

${ }^{16}$ Idem, Uwagi, s. 153.

${ }^{17}$ Zob. ibidem, s. $152-153$.

${ }^{18}$ Por. znalezione w osadach podkrakowskich formy odlewnicze, które znacznie różnią się od tej z okolic Kalisza, zob. B. Gediga, W kręgu kultury celtyckiej [w:] M. Derwich, A. Żurek (red.), Polska. Dzieje cywilizacji i narodu. U źródeł Polski do roku 1038, Warszawa-Wrocław
} 2002, s. 90. 
Oczywiście nie oznacza to, że ich brak wśród dotychczasowych znalezisk jest równoznaczny z wykluczeniem istnienia mennicy, ponieważ do czasów współczesnych mogły się nie zachować, ale uzasadnia sceptycyzm i zaleca ostrożność.

Trzeba także zauważyć, że w badanym okresie ogół plemion celtyckich czasy świetności swojej cywilizacji miał już za sobą, a wręcz znajdował się w okresie schyłkowym znaczenia politycznego i kulturowego. Dlatego trudno zgodzić się $\mathrm{z}$ twierdzeniem, aby jakieś drobne skupiska Bojów zamieszkujące okolice dzisiejszego Kalisza mogły bić własną monetę w drugiej połowie I w. przed Chr. (s. 93) w nowym, zapewne gęsto już zasiedlonym regionie, niedługo po opuszczeniu swoich wcześniejszych siedzib.

Nie mniej ważne jest też pytanie, czy Bojowie w ogóle przebywali w tym rejonie $^{19}$ po ustąpieniu ze swych pierwotnych siedzib lokalizowanych w Kotlinie Czeskiej, przed uciekającymi znad dolnego Menu Markomanami pod koniec I w. przed Chr. (Vell. 2, 108; Tac., Germ. 42; Ann. 2, 45). Tymczasem dobrze poświadczone $\mathrm{w}$ materiale archeologicznym osadnictwo celtyckie znajduje się w południowej Polsce, głównie na środkowym Śląsku i w okolicach dzisiejszego Krakowa ${ }^{20}$.

W świetle przytoczonych uwag monety, którym miejsce powstania przypisuje się w Jankowie w okolicy dzisiejszego Kalisza, należałoby uznać za przypadkowe znaleziska, które trafiły tam drogą handlu lub wymiany, jak w przypadku monet rzymskich, lub co najwyżej za dowód świadczący o obecności w tym rejonie jakiejś grupy ludności celtyckiej lub może tylko zlatenizowanej ludności kultury przeworskiej $^{21}$, ale niekoniecznie Bojów. Niewykluczone, że w skład tej grupy mogły również wchodzić inne plemiona czy związki plemienne, w czym znaczny udział miały także ludy germańskie ${ }^{22}$.

Podsumowując, należy stwierdzić, że zaprezentowana przez autorów referatu hipoteza o pisaniu nowej historii w dziejach znalezisk w okolicach Kalisza (s. 87)

\footnotetext{
${ }^{19}$ Zob. Celtowie, [w:] SSS, 1, 1961, s. 227; por. też bardzo trafne uwagi na temat osadnictwa celtyckiego w Polsce na podstawie źródeł pisanych: Z. Woźniak, Celtowie w Polsce, (Nauka dla Wszystkich, 68), Kraków 1968, s. 13; badacz stwierdził, że południowa Polska stanowiła strefę bezpośrednio przyległą do obszarów zajętych bezspornie przez Celtów na terenie Czech, aczkolwiek istnieją pewne przesłanki, na podstawie których można wnioskować o ich pobycie na ziemiach polskich.

${ }^{20}$ M. Olędzki, Ogólne, s. 155 (mapka osadnictwa), 167; A. Kokowski, Starożytna Polska, s. $31-42$.

${ }^{21}$ Celtowie, s. 228; Przeworska kultura, s. 390-391; M. Olędzki, Ogólne, s. 163; Przeworsk-Kultur, s. 540; J. Strzelczyk, Wandalowie i ich afrykańskie państwo, wyd. 2, Warszawa 2005, s. 39-40; A. Ziółkowski, Historia powszechna. Starożytność, Warszawa 2009, s. 772-775.

${ }^{22}$ J. Strzelczyk, Wandalowie. s. 49; A. Kokowski, Starożytna Polska, s. 164.
} 
wydaje się, jak na razie, pozbawiona przekonujących dowodów i wymagałaby dodatkowych badań lub silniejszego umocowania w materiale źródłowym popartym nowymi znaleziskami. Dlatego sądzę, że także przedwcześnie uznano wspomniane zabytki za produkty „mennicy kaliskiej”, co sugerowałoby istnienie jakiejś dobrze zorganizowanej produkcji noszącej przynajmniej znamiona „masowości” przy obecnie stwierdzonej jej incydentalności. Natomiast nie przesądza to o zajmowaniu tego terenu między innymi przez pewne grupy ludności celtyckiej, funkcjonującej w oderwaniu od swego głównego trzonu zajmującego południowo-zachodnią Polskę, egzystującej w ramach kultury przeworskiej. 